\title{
Pemahaman Konsep Jihad Ditinjau Dari Identifikasi Kelompok, Persepsi Ancaman Antar-Kelompok, Dan Kepribadian
}

\section{(Understanding The Concept Of Jihad Reviewed From Identification Of Groups, Perception Of Inter-Group Threats, And Personality)}

\author{
Esti Zaduqisti \\ Fakultas Ushuluddin, Adab, dan Dakwah, Institut Agama Islam Negeri Pekalongan \\ esti.zaduqisti@iainpekalongan.ac.id
}

\begin{abstract}
Abstrak
Penelitian ini bertujuan untuk mengetahui: (1) pengaruh identifikasi kelompok, persepsi ancaman antar-kelompok, dan kepribadian terhadap pemahaman konsep jihad damai. (2) pengaruh identifikasi kelompok, persepsi ancaman antar-kelompok, dan kepribadian terhadap pemahaman konsep jihad defensif. (3) pengaruh identifikasi kelompok, persepsi ancaman antar-kelompok, dan kepribadian terhadap pemahaman konsep jihad ofensif. Jenis penelitian ini adalah kuantitatif non-eksperimental, dengan alat bantu SPSS 16 teknik analisis yang digunakan adalah analisis regresi berganda. Subjek penelitian berjumlah 432 mahasiswa. Instrumen yang digunakan dalam penelitian adalah dengan menggunakan angket yang terdiri dari 8 skala; (1) Skala pertama adalah skala pemahaman konsep Jihad damai, (2) skala pemahaman konsep Jihad defensif, (3) Skala ketiga adalah skala pemahaman konsep Jihad ofensif , (4) skala identifikasi kelompok, (5) Skala Persepsi Ancaman Antar-Kelompok Simbolik, (6) Skala Persepsi Ancaman Antar-Kelompok Realistik, (7) Skala Kepribadian Otoritarian, dan (8) Skala Kepribadian Fundamentalis. Hasil penelitian diperoleh kesimpulan bahwa: (1) Identifikasi terhadap kelompok radikal, Persepsi ancaman-antar kelompok (baik simbolik maupun realistik),dan kepribadian (baik otoritarian maupun fundamentalis) berpengaruh secara signifikan terhadap pemahaman konsep jihad damai; (2) Identifikasi terhadap kelompok radikal, persepsi ancaman-antar kelompok (baik simbolik maupun realistik), dan kepribadian (baik otoritarian maupun fundamentalis) berpengaruh secara signifikan terhadap pemahaman konsep jihad defensif; dn (3) Identifikasi terhadap kelompok radikal, persepsi ancaman-antar kelompok (baik simbolik maupun realistik),dan kepribadian (baik otoritarian maupun fundamentalis) berpengaruh secara signifikan terhadap pemahaman konsep jihad ofensif .
\end{abstract}

Kata kunci: Pemahaman Konsep Jihad, Identifikasi Kelompok, Persepsi Ancaman Antar-Kelompok, Kepribadian.

\begin{abstract}
This study aims are to determine: (1) the influence of group identification, perceptions of inter-group threats, and personality towards understanding the concept of peaceful jihad. (2) the influence of group identification, perceptions of inter-group threats, and personality towards understanding the concept of defensive jihad. (3) the influence of group identification, perceptions of inter-group threats, and personality towards understanding the concept of offensive jihad. The research type is quantitative nonexperimental, the analysis technique used is multiple regression analysis with SPSS 16. The research subjects were 432 students. The instrument is a questionnaire consisting of 8 scales; (1) The first scale is the scale of understanding the concept of peaceful Jihad, (2) the scale of understanding the concept of defensive Jihad, (3) The third scale is the scale of understanding the concept of offensive Jihad, (4) scale of group identification, (5) Symbolic Threat Perception Scale, (6) Realistic Intergroup Threat Perception Scale, (7) Authoritarian Personality Scale, and (8) Fundamentalist Personality Scale. The results of the study concluded that: (1) Identification of radical groups, Perception of inter-group threats (both symbolic and realistic), and personalities (both authoritarian and fundamentalist) significantly influence the
\end{abstract}


understanding of the concept of peaceful jihad; (2) Identification of radical groups, perceptions of intergroup threats (both symbolic and realistic), and personalities (both authoritarian and fundamentalist) significantly influence the understanding of the concept of defensive jihad; and (3) Identification of radical groups, perceptions of inter-group threats (both symbolic and realistic), and personalities (both authoritarian and fundamentalist) significantly influence the understanding of the concept of offensive jihad.

Keywords: Understanding of the Jihad Concept, Group Identification, Perceptions of Inter-Group Threats, Personality.

\section{Pendahuluan}

Di Indonesia, aksi terorisme menjadi fenomena yang mengkhawatirkan. Bom Bali di tahun 2002 yang menewaskan 202 orang merupakan aksi terorisme yang paling memprihatinkan (Asthana \& Nirmal, 2009). Aksi terorisme di Indonesia akhir-akhir ini cukup mereda. Akan tetapi, banyak pihak berpendapat bahwa potensi terorisme di negara berpenduduk Muslim terbesar di dunia ini masih sangat besar. Bukti konkritnya adalah penangkapan polisi terhadap sejumlah oknum yang bersimpati dan mendukung ISIS atau IS ("Indonesia arrests six people, including 10-year-old child, for attempting to join Islamic State”, 2014).

Banyak kalangan, termasuk para ulama, memandang bahwa aksi terorisme yang dilakukan oleh sejumlah kelompok radikal tersebut tidak mencerminkan Islam, bahkan sangat bertentangan atau kontradiktif dengan esensi ajaran Islam (Kabir, 2006; Werbner, 2005). Akan tetapi, anggota kelompok radikal tersebut justru berkeyakinan bahwa aksi yang mereka lakukan dilandaskan pada apa yang mereka sebut sebagai Jihad (Ahmad, 2011; Post, Sprinzak, \& Denny, 2003). Dari sinilah kemudian mengemuka perdebatan mengenai apa yang sebenarnya dimaksud dengan Jihad dalam ajaran Islam. Klarifikasi terhadap pemahaman mengenai konsep Jihad ini adalah langkah yang sangat penting, dan ini menjadi salah satu tujuan dari penelitian ini.

Sejumlah pemikir (Moghadam, 2008; Muluk \& Sumaktoyo, 2013) berargumen bahwa salah satu akar penyebab aksi terorisme di dunia Islam adalah kecenderungan sejumlah Muslim untuk meyakini konsep Jihad ofensif sebagai satu satunya konsep Jihad yang paling benar. Dalam konteks ini, kelompok radikal Islam justru berpandangan bahwa aksi-aksi sadis seperti bom bunuh diri, penculikan, perampokan, pemenggalan kepala terhadap pihak-pihak yang dipandang sebagai musuh bukanlah aksi terorisme tetapi aksi peperangan suci (holy war) (Hiro, 2014). Mengacu pada sejumlah literatur, ada banyak faktor yang bisa menyebabkan mengapa seorang Muslim berkencenderungan untuk memahami konsep Jihad sebagai Jihad ofensif, bukannya Jihad defensif dan terlebih lagi Jihad damai (King, \& Taylor, 2011). Faktor-faktor ini secara mendasar bisa dikelompokkan ke dalam dua kategori: (1) faktor situasional atau antar-kelompok, dan (2) faktor individual atau kepribadian. Masing-masing faktor ini juga bisa saling berinteraksi, sehingga pemahaman Muslim mengenai ketiga jenis Jihad di atas akan dipengaruhi oleh kombinasi antara faktor situasional dan faktor individual tersebut. Dalam penelitian ini, kami memfokuskan faktor situsional pada persepsi ancaman antar-kelompok (perceived intergroup threat) sementara faktor individual kami tekankan pada tiga aspek: (1) kepribadian otoritarian, (2) fundamentalisme beragama, dan (3) identifikasi terhadap kelompok dan tokoh radikal Islam. Asumsi yang kami ajukan dan yang akan diuji secara empiris melalui penelitian ini adalah bahwa semakin mendalam Muslim mempersepsi negara Barat sebagai ancaman terhadap Islam dan Muslim serta semakin otoritarian dan fundamentalis kepribadian mereka, maka semakin besar kemungkinan bahwa mereka memahami konsep Jihad sebagai Jihad ofensif dibandingkan dengan Jihad defensif, terlebih lagi Jihad damai. Asumsi kedua adalah bahwa pengaruh persepsi ancaman kelompok, kepribadian otoritarian dan fundamentalis tersebut terhadap pemahaman konsep Jihad ofensif akan semakin kuat jika Muslim mengidentifikasi secara kuat dengan kelompok-kelompok ataupun tokoh-tokoh Islam radikal.

Pekalongan, sebagai salah satu daerah yang ada di Indonesia dan termasuk lokasi yang rawan terhadap pengaruh radikalisme dan terorisme. Penelitian Muniroh, dkk. (2012) yang berjudul "Perempuan di Balik Teroris: Kajian Religiusitas, Penyesuaian Diri dan Pola Relasi Suami Isteri Tersangka Teroris", dengan seting penelitian di kota Pekalongan, mengindikasikan bahwa pekalongan termasuk daerah yang rawan terhadap pengaruh bentuk bentuk radikalisme. Mahasiswa STAIN 
Pekalongan, sebagai remaja yang tentunya tidak mustahil juga mempunyai potensi untuk terpengaruh dengan paham-paham yang radikal, oleh sebab itu penelitian ini mencoba mengungkap sejauh mana pemahaman mereka tentang pemahaman jihad yang didalamnya terdapat dimensi jihad ofensif, sedang jihad ofensif itu sendiri juga identik dengan radikalisme.

Dalam kajian teori mengenai pemahaman konsep jihad. Dari pemaknaan konsep jihad yang merujuk pada 3 varian kelompok, yaitu kelompok konservatif, kelompok liberal, dan kelompok moderat (Qardhawi, 2010), teridentifikasi beberapa indikator yang bisa menjelaskan sebuah variabel pemahaman konsep jihad. Indikator-indikator yang diindetifikasikan dari beberapa kajian literatur mengenai pemaknaan konsep jihad, setidaknya termuat dalam tiga dimensi. Dimensi pertama adalah jihad damai, yang kedua jihad defensif, dan yang ketiga adalah jihad ofensif. Jihad damai diartikan sebagai bentuk jihad yang bukan dalam bentuk perang, jenis jihad ini antara lain adalah mengendalikan hawa nafsu, menyempurnakan keimanan dan akhlaq, pengorbanan, bekerja dengan baik, memimpin dengan adil, berdagang dengan jujur, membantu yang lemah, dan bersabar. (Qardhawi, 2010; Aziz, dkk. 2013; dan Shihab, 1996). Jenis jihad ini diklasifikasikan sebagai bentuk jihad yang berupaya untuk mempertahankan diri dari serangan musuh. Jenis jihad ini memiliki 4 indikator berupa; 1) mempertahankan keberadaan Islam dan kesucian nya, 2) resistensi terhadap musuh yang melanggar hak-hak Muslim, 3) mempertahankan status muslim di wilayah yang terjadi konflik dengan non muslim, 4) mengusir penyerang/ penjajah dari tanah air. (Janati, 1984). Jenis jihad ini adalah bentuk jihad yang berupa peperangan yang bertujuan untuk ekspansi (futûhât), yakni upaya memperluas wilayah kekuasaan, serta perang untuk mewujudkan kemenangan dan kesyahidan serta pemisahan total hubungan muslim dan non muslim (Labib, 2007; \& Al-nabhani, 1994).

Identifikasi kelompok adalah identifikasi yang dilakukan oleh individu yang menunjuk pada sejauhmana individu sebagai anggota suatu kelompok merasakan ikatan yang kuat terhadap kelompoknya. Menurut teori social identity (Tajfel \& Turner, 1986), identifikasi kelompok akan memprediksi pemahaman yang dimiliki seseorang tersebut sesuai dengan kelompok yang diidentifikasikannya. Berdasarkan penggolongan muslim ke dalam 3 kategori (liberal, moderat, dan radikal) menurut Yusuf al-Qardhawi (2010) kelompok radikal akan memiliki kecenderungan memahami jihad sebagai bentuk jihad ofensif. Dalam konteks penelitian ini, maka semakin tinggi tingkat identifikasi Muslim terhadap kelompok dan tokoh radikal Islam maka semakin kuat untuk memahami jihad sebagai jihad ofensif.

Sebagaimana dijelaskan dalam konsep teori mengenai Intergroup Threat Theory Persepsi ancaman antar-kelompok, terbagi ke dalam dua jenis. Pertama adalah ancaman antar-kelompok yang bersifat simbolis (symbolic threat), artinya bahwa keterancaman sesorang terhadap kelompok lain bersumber dari persepsi sesorang tersebut terhadap nilai-nilai, norma-norma, pandangan-hidup, dan budaya keompok-lain (outgroups) yang dianggap bertentangan dan tidak sesuai dengan nilai-nilai, norma-norma, pandangan-hidup, dan budaya kelompok-sendiri (in-group). Kedua adalah ancaman antar-kelompok yang bersifat realistik (realistic threat) yang diartikan sebagai ancaman yang bermuara pada persepsi bahwa kekuatan ekonomi, kekuasaan ataupun hal-hal lain seperti teknologi yang dimiliki kelompok-lain menyaingi atau lebih tepatnya, mengungguli kelompok-sendiri.

Rogers dkk. (2007) berargumen bahwa secara umum, persepsi ancaman antar-kelompok, disamping juga perspesi ketidakadilan yang memicu keresahan, menjadi katalis munculya radikalisme dan ekstremisme pada seumlah kalangan Muslim, yang pada akhirnya memicu aksi-aksi terorisme.Dalam konteks hubungan Islam dan Barat, sejumlah Muslim mempersepsikan bahwa dominasi Amerika Serikat khususnya dan negara-negara Barat umumnya dalam hal arus cepat globalisasi, sekularisasi, dan Westernisasi telah mengancam nilai-nilai tradisi Islam. Persepsi ancaman simbolik ini terutama dirasakan oleh kelompok Muslim fundamentalis, yang selanjutnya berpotensi memunculkan radikalisme Islam dan terorisme yang mengatasnamakan Islam (Moghaddam, 2012). Akan tetapi, ancaman realistik berupa supremasi Barat dibandingkan negara-negara Islam dalam hal ekonomi, teknologi, yang dikombinasikan dengan faktor-faktor lain seperti pendudukan Israel atas Palestina yang selalu didukung oleh Barat, juga menadi pemicu perasaan sejumlah Muslim bahwa kekuataan Islam sedang di bawah ancaman (Fair \& Shepherd, 2006). Berdasarkan argumentasi yang dibangun atas dasar teori teori di atas, kami berasumsi bahwa baik persepsi ancaman antar-kelompok simbolik dan realistik yang dirasakan oleh Muslim dalam hubungannya dengan Barat berpotensi menimbulkan radikalisme dan ekstremisme Islam.Dalam penelitian ini, bentuk radikalisme dan ekstremisme tersebut kami fokuskan pada pemahaman Muslim atas jenis-jenis Jihad. Secara lebih 
spesifik, kami memiliki premis bahwa semakin tinggi persepsi ancaman simbolik dan realistik yang dialami oleh Muslim terhadap pihak Barat semakin besar kemungkinan bahwa Muslim memahami konsep Jihad lebih sebagai Jihad ofensif dibandingkan dengan Jihad defensif maupun Jihad damai.

Kepribadian sebagai salah satu faktor yang mempengaruhi pemahaman seseorang oleh Altemeyer (1981, 1988) terbagi ke dalam dua jenis kepribadian, yaitu kepribadian otoritarian dan kepribadian fundamentalis. Kepribadian otoritarian memiliki 3 ciri, yaitu: (1) ketundukan yang bersifat otoritarian, (2) agresi yang bersifat otoritarian, dan (3) konvesionalisme. Berdasarkan tiga komponen ini, kepribadian otoritarian diartikan sebagai kepribadian yang ditandai dengan ketundukan membabi-buta terhadap otoritas, sikap agresif terhadap kelompok-lain yang dianggap menyimpang dari nila-nilai dan budaya kelompok-sendiri, serta fanatisme terhadap nilai-nilai tradisional (Heaven \& Bucci, 2001). Sementara itu, kepribadian fundamentalis ditandai dengan keyakinan kuat terhadap kebenaran agama yang diyakini, intoleransi terhadap perdebatan yang bersifat keagamaan serta terhadap pihak-pihak lain yang nilai-nilai dan perilakunya dianggap tidak sesuai dengan standar yang diyakini (Kunst, Thomsen, \& Sam, 2014). Dari penjelasan ini, sebuah premis bisa ditarik dimana kepribadian fundamentalis memiliki tendensi untuk berkontribusi dalam menggiring Muslim untuk memahami Jihad sebagai Jihad ofensif. Hal ini didasarkan pada temuan bahwa para pelaku Jihad ofensif diciri khasi dengan adanya kebencian patologis serta intoleransi terhadap pihak-pihak yang dianggap musuh, yang dalam hal ini adalah pihak Barat (Gottschalk dan Gottschalk (2004). Secara empiris, argumen ini sesuai dengan hasil studi dari Muluk dan Sumaktoyo (2013) yang melaporkan bahwa Muslim dengan fundamentalisme beragama yang tinggi cenderung mendukung bentuk atau model Jihad kekerasan.

Dari uraian latar belakang masalah tersebut diatas, maka disusunlah hipotesis sebagai berikut:

1. Ada pengaruh yang signifikan identifikasi terhadap kelompok, persepsi ancaman antar-kelompok simbolik, persepsi ancaman antar-kelompok realistik, kepribadian otoritatif, dan kepribadian fundamentalis terhadap pemahaman konsep jihad damai.

2. Ada pengaruh yang signifikan identifikasi terhadap kelompok, persepsi ancaman antar-kelompok simbolik, persepsi ancaman antar kelompok realistik, kepribadian otoritatif, dan kepribadian fundamentalis terhadap pemahaman konsep jihad defensive,

3. Ada pengaruh yang signifikan identifikasi terhadap kelompok, persepsi ancaman antar-kelompok simbolik, persepsi ancaman antar-kelompok realistik, kepribadian otoritatif, dan kepribadian fundamentalis terhadap pemahaman konsep jihad ofensif.

\section{Metode Penelitian}

Penelitian ini merupakan penelitian kuantitatif dimana setiap konstruk atau variabel diukur melalui skala. Variabel bebas dalam penelitian ini meliputi 5 variabel, yaitu:1) Identifikasi kelompok, 2) persepsi ancaman antar-kelompok simbolik, 3) persepsi ancaman antar-kelompok realistik, 4) kepribadian otoritarian, dan 5) kepribadian fundamentalisme. Variabel terikat dalam penelitian ini meliputi 3 variabel, yaitu: 1) pemahaman konsep jihad damai, 2) pemahaman konsep jihad defensif, dan 3) pemahaman konsep jihad ofensif.

Populasi dalam penelitian ini adalah mahasiswa Muslim di STAIN Pekalongan. Sementara sampel penelitian dibatasi pada mahasiswa muslim dari sejumlah program studi dalam lingkup STAIN Pekalongan. Populasi dalam penelitian ini adalah mahasiswa STAIN Pekalongan yang berjumlah kurang lebih 6000 mahasiswa. Sedang sampel yang akan digunakan adalah kurang lebih 432 mahasiswa. Besaran ini adalah mengikuti teknik penentuan besaran sampel yang ditentukan oleh Krejcie (Sugiyono, 2007; Krejcie \& Morgan, 1970). Sampel penelitian ditarik secara non-random, menggunakan metode convenience sampling (Gravetter \& Forzano, 2015) dimana sampel didapatkan atas dasar kesediaan mahasiwa untuk berpartisipasi dalam penelitian dengan mengisi kuesinoer yang diberikan

Instrumen yang digunakan dalam penelitian berupa angket atau kuesioner yang terdiri dari sejumlah skala untuk mengukur masing-masing variabel penelitian. Skala pertama adalah skala pemahana konsep Jihad damai, dengan indikator: memberantas kebodohan, memberi pertolongan, beribadah dan mencari ilmu. Skala kedua adalah skala pemahana konsep Jihad defensif, dengan indicator: mempertahankan diri dari serangan, mengusir musuh, dan mempertahankan hak. Skala ketiga adalah skala pemahaman konsep Jihad ofensif, dengan indikator: Memperluas kekuasaan, Berperang untuk menegakkan Negara Islam, Menolak produk barat, Perang melawan pemerintah yang tidak 
menerapkan idiologi Islam, dan Perang balas dendam. Skala keempat, adalah skala identifikasi kelompok yang diadaptasi dan diterjemahkan dari skala yang dibuat oleh Sindic dan Reicher (2009), dengan indikator: Idola terhadap tokoh kelompok, Merasa memiliki ikatan, Refleksi diri terhadap kelompok. Skala kelima adalah skala untuk mengukur persepsi ancaman antar-kelompok simbolik yang diadaptasi dari studi oleh Mashuri, Zaduqisti, Sakdiah, dan Sukmawati (2014) serta oleh Mashuri dan Zaduqisti (2015), dengan indikator: Pertentangan nilai/budaya, Pertentangan pemikiran, dan Pergeseran budaya/nilai/norma. Skala keenam adalah skala untuk mengukur persepsi ancaman antarkelompok realistic yang diadaptasi dari studi oleh Mashuri, Zaduqisti, Sakdiah, dan Sukmawati (2014) serta oleh Mashuri dan Zaduqisti (2015), dengan indikator: Persaingan ekonomi, Persaingan ilmu pengetahuan, Persaingan kekuasaan/pengaruh, Persaingan kesejahteraan. Skala ketujuh skala untuk mengukur kepribadian otoritarian yang yang diterjemahkan peneliti dari skala yang dibuat oleh Zakrisson (2005), dengan indikator: Ketundukan yang bersifat otoritarian, Agresi yang bersifat otoritarian, dan Konvesionalisme. Skala kedelapan adalah skala untuk mengukur kepribadian fundamentalis atau fundamentalisme beragama yang juga diadopsi dari skala yang telah dikonstruksi oleh Mashuri dan Zaduqisti (2015) atas dasar skala asli yang dibuat oleh Altemeyer dan Hunsberger (1992), dengan indikator: keyakinan akan kebenaran diri, intoleransi terhadap perbedaan, dan pertentangan agama dan ilmu.

Analisis data yang digunakan dalam penelitian ini adalah analisis regresi berganda yang dilaksankan dengan menggunakan tiga tahap sesuai dengan variabel terikat penelitian ini. Analisis tersebut menggunakan SPSS 18. Dengan model analisis ini, pengaruh masing-masing variabel independen (bebas) akan dilihat besaran sumbangannya terhadap masing-masing variabel terikat secara bertahap (dalam 3 tahap).

\section{Hasil Penelitian}

\section{Deskripsi Respoden Penelitian}

Responden dalam penelitian ini berjumlah 432 (laki-laki 128 mahasiswa, dan perempuan 301 mahasiswa) dengan rentang usia yang bervariasi yaitu mulai dari usia 17 tahun sampai dengan 37 tahun. Menempati pada skor yang paling banyak adalah mahasiswa yang berusia 20 tahun (27\%) dan 21 tahun (21\%). Lebih Detail, deskripsi responden berdasarkan usia (tabel 1) dan berdasarakan program studi (tabel 2).

\begin{tabular}{ccc} 
& Tabel 1. Responden Berdasarkan Usia & \\
\hline Usia & Jumlah & Prosentase \\
\hline 17 tahun & 10 & 2.3 \\
18 tahun & 44 & 10.2 \\
19 tahun & 81 & 18.8 \\
20 tahun & 115 & 26.6 \\
21 tahun & 89 & 20.6 \\
22 tahun & 35 & 8.1 \\
23 tahun & 20 & 4.6 \\
24 tahun & 12 & 2.8 \\
25 tahun & 12 & 2.8 \\
26 tahun & 1 & .2 \\
27 tahun & 3 & .7 \\
28 tahun & 1 & .2 \\
37 tahun & 1 & .2 \\
Tidak mengisi & 8 & 1.9 \\
Total & 432 & 100.0 \\
\hline
\end{tabular}

Sumber: hasil skoring angket penelitian 2015 
Tabel 2. Deskripsi Responden Berdasar Program Studi

\begin{tabular}{ll}
\hline Jenis Kelamin & Jumlah Responden \\
\hline Akhlaq Tasawuf (AT) & 16 \\
Bimbingan Konseling Islam (BKI) & 105 \\
Ekonomi Syariah (Ekos) & 10 \\
Komunikasi dan Penyiaran Islam (KPI) & 6 \\
Pendidikan Agama Islam (PAI) & 163 \\
Pendidikan Bahasa Arab (PBA) & 97 \\
Tafsir Hadits (TH) & 9 \\
Pendidikan Guru Madrasah Ibtidaiyah (PGMI) & 14 \\
Tidak mengisi & 12 \\
Total & 432 \\
\hline
\end{tabular}

Sumber: hasil skoring angket penelitian 2015

\section{Data Pemahaman Konsep Jihad Damai (Y1)}

Secara teoritis, skor masing-masing item skala pemahaman konsep jihad damai bergerak dari 1 sampai 7 dengan jumlah aitemnya sebanyak 8 , maka skor totalnya bergerak dari 8 ( $8 \times 1)$ sampai dengan 56 ( $8 \times$ 7). Sehingga luas interval sebarannya adalah $56-8=48$, dengan satuan deviasi standarnya bernilai 48 : $6=8$ dan rerata hipotetis sebesar $\mathrm{M}=(8+56): 2=32$. Data hasil penelitian menunjukkan bahwa skor terendah skala pemahaman konsep jihad damai adalah 16 dan skor tertinggi 56, rerata empiris $\mathrm{M}=45,7$ dan standar deviasi sebesar 8,57. Data tersebut menunjukkan bahwa rerata empiris lebih besar dari rerata hipotesis.

Data di atas berarti bahwa reponden dalam penelitian memiliki pemahaman mengenai konsep jihad damai lebih tinggi dibanding rerata hipotesisnya. Untuk pengkategorisasian pemahaman konsep jihad damai, maka dibuat tiga kategori yaitu; Tinggi, jika skor $>M+2 \mathrm{~s}(32+2 \times 8,57=49,14=49)$, Sedang, jika skor $\mathrm{M}-2 \mathrm{~s}<\mathrm{X}<\mathrm{M}+2 \mathrm{~s}(15<\mathrm{X}<49)$, dan Rendah, jika skor $<\mathrm{M}-2 \mathrm{~s}(<15)$. (Keterangan : $\mathrm{M}=$ Mean teoritis; $\mathrm{s}=$ Standar Deviasi). Berikut tabel 3 menyajikan data pemahaman konsep jihad damai dari responden yang dikategorikan ke dalam 3 jenis kelas (rendah, sedang, dan tinggi).

Tabel 3. menunjukkan bahwa sebagian besar responden yang memiliki pemahaman konsep jihad damai dalam kategori sedang, yaitu 254 orang atau 58,8\%, sisanya masuk kategori tinggi, berjumlah 172 orang $(39,8 \%)$. Responden yang masuk dalam kategori rendah adalah $0 \%$, artinya bahwa tidak ada responden yang masuk dalam kateri rendah dalam memahami konsep jihad damai. Ada 6 responden yang dinyatakan missing value, hal ini disebabkan oleh ketidaklengkapan responden dalam menjawab skala pemahaman konsep jihad damai.

Tabel 3. Kategorisasi skor pemahaman konsep jiha damai

\begin{tabular}{cccc}
\hline Kategori & Skor & Frekuensi & Prosentase (\%) \\
\hline Tinggi & $>49$ & 172 & 39,8 \\
Sedang & $15<\mathrm{X}<49$ & 254 & 58,8 \\
Rendah & $<15$ & 0 & 0 \\
Missing & & 6 & 1,4 \\
Total & & 432 & 100 \\
\hline
\end{tabular}

Sumber: hasil skoring skala penelitian 2015

\section{Data Pemahaman Konsep Jihad Defensif (Y2)}

Secara teoritis, skor masing-masing item skala pemahaman konsep jihad defensif bergerak dari 1 sampai 7 dengan jumlah aitemnya sebanyak 8, maka skor totalnya bergerak dari 8 (8 x 1) sampai dengan 56 ( $8 \times 7$ ). Sehingga luas interval sebarannya adalah $56-8=48$, dengan satuan deviasi standarnya bernilai 48: $6=8$ dan rerata hipotetis sebesar $M=(8+56): 2=32$. Data hasil penelitian menunjukkan bahwa skor terendah skala pemahaman konsep jihad defensif adalah 15 dan skor tertinggi 56, rerata empiris $\mathrm{M}=42,1$ dan standar deviasi sebesar 8,9. Data tersebut menunjukkan bahwa rerata empiris lebih besar dari rerata hipotetis.

Data di atas berarti bahwa reponden dalam penelitian memiliki pemahaman mengenai konsep jihad defensif lebih tinggi dibanding rerata hipotesisnya. Untuk pengkategorisasian pemahaman konsep jihad defensif, maka dibuat tiga kategori yaitu; Tinggi, jika skor $>\mathrm{M}+2 \mathrm{~s}(32+2 \times 8,9=49,8=50)$, Sedang, 
jika skor $\mathrm{M}-2 \mathrm{~s}<\mathrm{X}<\mathrm{M}+2 \mathrm{~s}(15<\mathrm{X}<49)$, dan Rendah, jika skor $<\mathrm{M}-2 \mathrm{~s}(<15)$. (Keterangan : $\mathrm{M}=$ Mean teoritis; $\mathrm{s}=$ Standar Deviasi). Berikut tabel 4 menyajikan data pemahaman konsep jihad defensif dari responden yang dikategorikan ke dalam 3 jenis kelas (rendah, sedang, dan tinggi).

Tabel 4. Kategorisasi skor pemahaman konsep jihad defensive

\begin{tabular}{cccc}
\hline Kategori & Skor & Frekuensi & Prosentase (\%) \\
\hline Tinggi & $>50$ & 79 & 18,29 \\
Sedang & $15<\mathrm{X}<49$ & 346 & 80,1 \\
Rendah & $<15$ & 0 & 0 \\
Missing & - & 7 & 1,7 \\
Total & & 432 & 100 \\
\hline
\end{tabular}

Sumber: hasil skoring skala penelitian 2015

Tabel 4. menunjukkan bahwa sebagian besar responden yang memiliki pemahaman konsep jihad defensif dalam kategori sedang, yaitu 346 orang atau 80,1\%, sisanya masuk kategori tinggi, berjumlah 79 orang $(18,29 \%)$. Responden yang masuk dalam kategori rendah adalah $0 \%$, artinya bahwa tidak ada responden yang masuk dalam kateri rendah dalam memahami konsep jihad defensif. Ada 7 responden yang dinyatakan missing value, hal ini disebabkan oleh ketidaklengkapan responden dalam menjawab skala pemahaman konsep jihad defensif.

\section{Data Pemahaman Konsep Jihad Damai Ofensif (Y3)}

Secara teoritis, skor masing-masing item skala pemahaman konsep jihad ofensif bergerak dari 1 sampai 7 dengan jumlah aitemnya sebanyak 8 , maka skor totalnya bergerak dari 8 ( $8 \times 1)$ sampai dengan $56(8 \mathrm{x}$ 7). Sehingga luas interval sebarannya adalah $56-8=48$, dengan satuan deviasi standarnya bernilai 48 : $6=8$ dan rerata hipotetis sebesar $\mathrm{M}=(8+56): 2=32$. Data hasil penelitian menunjukkan bahwa skor terendah skala pemahaman konsep jihad ofensif adalah 8 dan skor tertinggi 48, rerata empiris $\mathrm{M}=$ 32,85 dan standar deviasi sebesar 9,8. Data tersebut menunjukkan bahwa rerata empiris hampir sama dengan rerata hipotetis.

Data di atas berarti bahwa reponden dalam penelitian memiliki pemahaman mengenai konsep jihad ofensif lebih tinggi dibanding rerata hipotesisnya. Untuk pengkategorisasian pemahaman konsep jihad ofensif, maka dibuat tiga kategori yaitu; tinggi, jika skor $>\mathrm{M}+2 \mathrm{~s}(32+2 \times 9,8=51,6=52)$, sedang, jika skor $\mathrm{M}-2 \mathrm{~s}<\mathrm{X}<\mathrm{M}+2 \mathrm{~s}(12<\mathrm{X}<52)$, dan rendah, jika skor $<\mathrm{M}-2 \mathrm{~s}(<12)$. (Keterangan $: \mathrm{M}=$ Mean teoritis; $\mathrm{s}=$ Standar Deviasi). Berikut tabel 5 menyajikan data pemahaman konsep jihad ofensif dari responden yang dikategorikan ke dalam 3 jenis kelas (rendah, sedang, dan tinggi).

Tabel 5. Kategorisasi skor pemahaman konsep jihad ofensif

\begin{tabular}{cccc}
\hline Kategori & Skor & Frekuensi & Prosentase (\%) \\
\hline Tinggi & $>52$ & 8 & 1,9 \\
Sedang & $12<\mathrm{X}<52$ & 413 & 95,6 \\
Rendah & $<12$ & 5 & 1,1 \\
Missing & - & 6 & 1,4 \\
Total & & 432 & 100 \\
\hline
\end{tabular}

Sumber: hasil skoring skala penelitian 2015

Tabel 5 menunjukkan bahwa sebagian besar responden yang memiliki pemahaman konsep jihad defensif dalam kategori sedang, yaitu 413 orang atau 95,6\%, yang masuk kategori tinggi, berjumlah 8 orang (1,9\%). Responden yang masuk dalam kategori rendah adalah $1,1 \%$, artinya bahwa tidak ada responden yang masuk dalam kateri rendah dalam memahami konsep jihad defensif. Ada 6 responden yang dinyatakan missing value, hal ini disebabkan oleh ketidaklengkapan responden dalam menjawab skala pemahaman konsep jihad ofensif.

\section{Data Identifikasi Terhadap Kelompok (X1)}

Secara teoritis, skor masing-masing item skala identifikasi terhadap kelompok bergerak dari 1 sampai 7 dengan jumlah aitemnya sebanyak 4, maka skor totalnya bergerak dari 4(4 x 1) sampai dengan 28 ( $4 \mathrm{x}$ 7). Sehingga luas interval sebarannya adalah $28-4=24$, dengan satuan deviasi standarnya bernilai 28 : 
$6=4.7$ dan rerata hipotetis sebesar $\mathrm{M}=(4+28): 2=16$. Data hasil penelitian menunjukkan bahwa skor terendah skala identifikasi terhadap kelompok adalah 4 dan skor tertinggi 20 , rerata empiris $\mathrm{M}=5,8$ dan standar deviasi sebesar 3,1. Data tersebut menunjukkan bahwa rerata empiris hampir sama dengan rerata hipotetis.

Data di atas berarti bahwa reponden dalam penelitian memiliki identifikasi terhadap kelompok lebih rendah dibanding rerata hipotesisnya. Untuk pengkategorisasian identifikasi terhadap kelompok, maka dibuat tiga kategori, yaitu; tinggi, jika skor $>\mathrm{M}+2 \mathrm{~s}(16+2 \times 3,1=22,2=22)$, sedang, jika skor $\mathrm{M}-2$ $\mathrm{s}<\mathrm{X}<\mathrm{M}+2 \mathrm{~s}(10<\mathrm{X}<22)$, dan rendah, jika skor $<\mathrm{M}-2 \mathrm{~s}(<10)$. (Keterangan : $\mathrm{M}=$ Mean teoritis; $\mathrm{s}=$ Standar Deviasi). Berikut tabel 6 menyajikan data identifikasi terhadap kelompok responden yang dikategorikan ke dalam 3 jenis kelas (rendah, sedang, dan tinggi).

Tabel 6. Kategorisasi skor identifikasi terhadap kelompok

\begin{tabular}{cccc}
\hline Kategori & Skor & Frekuensi & Prosentase (\%) \\
\hline Tinggi & $>22$ & 0 & 0 \\
Sedang & $10<\mathrm{X}<22$ & 48 & 11,1 \\
Rendah & $<10$ & 383 & 88,66 \\
Missing & - & 1 & 0,23 \\
Total & & 432 & 100 \\
\hline
\end{tabular}

Sumber: hasil skoring skala penelitian 2015

Tabel 6. menunjukkan bahwa sebagian besar responden memiliki identifikasi terhadap kelompok dalam kategori rendah, yaitu 383 orang atau 88,66\%. Dari Seluruh responden, identifikasi terhadap kelompok tidak ada yang termasuk dalam kategori tinggi. Responden yang termasuk dalam kategori sedang adalah $11,1 \%$, dan hanya 1 responden yang dinyatakan missing value.

\section{Data Persepsi Ancaman Antar-Kelompok Simbolik (X2)}

Secara teoritis, skor masing-masing item skala persepsi ancaman antar-kelompok simbolik bergerak dari 1 sampai 7 dengan jumlah aitemnya sebanyak 6, maka skor totalnya bergerak dari 6(6 x 1) sampai dengan $42(6 \times 7)$. Sehingga luas interval sebarannya adalah $42-6=36$, dengan satuan deviasi standarnya bernilai $42: 6=7$ dan rerata hipotetis sebesar $\mathrm{M}=(6+42): 2=24$. Data hasil penelitian menunjukkan bahwa skor terendah skala persepsi ancaman antar-kelompok simbolik adalah 6 dan skor tertinggi 42 , rerata empiris $\mathrm{M}=33,5$ dan standar deviasi sebesar 7,6. Data tersebut menunjukkan bahwa rerata empiris hampir sama dengan rerata hipotetis.

Data di atas berarti bahwa reponden dalam penelitian memiliki persepsi ancaman antar-kelompok simbolik lebih tinggi dibanding rerata hipotesisnya. Untuk pengkategorisasian persepsi ancaman antarkelompok simbolik, maka dibuat tiga kategori yaitu; tinggi, jika skor $>\mathrm{M}+2 \mathrm{~s}(24+2 \times 7,6=39,2=39)$, sedang, jika skor $\mathrm{M}-2 \mathrm{~s}<\mathrm{X}<\mathrm{M}+2 \mathrm{~s}(9<\mathrm{X}<39)$, rendah, jika skor $<\mathrm{M}-2 \mathrm{~s}(<9)$. (Keterangan : $\mathrm{M}=$ Mean teoritis; $\mathrm{s}=$ Standar Deviasi). Berikut tabel 7 menyajikan data identifikasi persepsi ancaman antar-kelompok simbolik responden yang dikategorikan ke dalam 3 jenis kelas (rendah, sedang, dan tinggi).

Tabel 7. Kategorisasi skor persepsi ancaman antar-kelompok simbolik

\begin{tabular}{cccc}
\hline Kategori & Skor & Frekuensi & Prosentase (\%) \\
\hline Tinggi & $>39$ & 108 & 25 \\
Sedang & $9<\mathrm{X}<39$ & 320 & 74,1 \\
Rendah & $<9$ & 3 & 0,7 \\
Missing & - & 1 & 0,2 \\
Total & & 432 & 100 \\
\hline
\end{tabular}

Sumber: hasil skoring skala penelitian 2015

Tabel 7. menunjukkan bahwa sebagian besar responden memiliki persepsi ancaman antar-kelompok simbolik dalam kategori sedang, yaitu 320 orang atau $74,1 \%$, kemudian diurutan berikutnya adalah kategori Tinggi (108 orang atau 25\%) dan kategori rendah 3 orang ( 0,7\%). Hanya 1 responden yang dinyatakan missing value.

Data Persepsi Ancaman Antar-Kelompok Realistik (X3)

Secara teoritis, skor masing-masing item skala persepsi ancaman antar-kelompok realistik bergerak dari 1 sampai 7 dengan jumlah aitemnya sebanyak 6, maka skor totalnya bergerak dari $6(6 \times 1)$ sampai 
dengan $42(6 \times 7)$. Sehingga luas interval sebarannya adalah $42-6=36$, dengan satuan deviasi standarnya bernilai $42: 6=7$ dan rerata hipotetis sebesar $\mathrm{M}=(6+42): 2=24$. Data hasil penelitian menunjukkan bahwa skor terendah skala persepsi ancaman antar-kelompok realistik adalah 6 dan skor tertinggi 42, rerata empiris $\mathrm{M}=32,4$ dan standar deviasi sebesar 8,2. Data tersebut menunjukkan bahwa rerata empiris hampir sama dengan rerata hipotetis.

Data di atas berarti bahwa reponden dalam penelitian memiliki persepsi ancaman antar-kelompok realistik lebih tinggi dibanding rerata hipotesisnya. Untuk pengkategorisasian persepsi ancaman antarkelompok realistik, maka dibuat tiga kategori yaitu; tinggi, jika skor $>\mathrm{M}+2 \mathrm{~s}(24+2 \times 8,2=40,4=40)$, sedang, jika skor $\mathrm{M}-2 \mathrm{~s}<\mathrm{X}<\mathrm{M}+2 \mathrm{~s}(8<\mathrm{X}<40)$, rendah, jika skor $<\mathrm{M}-2 \mathrm{~s}(<8)$, (Keterangan : $\mathrm{M}=$ Mean teoritis; $\mathrm{s}=$ Standar Deviasi). Berikut tabel 8 menyajikan data identifikasi persepsi ancaman antar-kelompok realistik responden yang dikategorikan ke dalam 3 jenis kelas (rendah, sedang, dan tinggi).

Tabel 8. Kategorisasi skor persepsi ancaman antar-kelompok realistik

\begin{tabular}{cccc}
\hline Kategori & Skor & Frekuensi & Prosentase (\%) \\
\hline Tinggi & $>40$ & 70 & 16,2 \\
Sedang & $8<\mathrm{X}<40$ & 354 & 81,8 \\
Rendah & $<8$ & 6 & 1,4 \\
Missing & - & 2 & 0,76 \\
Total & & 432 & 100 \\
\hline
\end{tabular}

Sumber: hasil skoring skala penelitian 2015

Tabel 8 menunjukkan bahwa sebagian besar responden memiliki persepsi ancaman antar-kelompok realistik dalam kategori sedang, yaitu 354 orang atau $81,8 \%$, kemudian diurutan berikutnya adalah kategori tinggi (70 orang atau 16,2\%) dan kategori rendah 6orang (1,4 \%). Hanya 2 responden yang dinyatakan missing value.

\section{Data Kepribadian Otoritarian (X4)}

Secara teoritis, skor masing-masing item skala kepribadian otoritarian bergerak dari 1 sampai 7 dengan jumlah aitemnya sebanyak 12, maka skor totalnya bergerak dari 12 (12 x 1) sampai dengan 84 (12 x 7). Sehingga luas interval sebarannya adalah $84-12=72$, dengan satuan deviasi standarnya bernilai 84: 6 $=14$ dan rerata hipotetis sebesar $\mathrm{M}=(12+84): 2=48$. Data hasil penelitian menunjukkan bahwa skor terendah skala kepribadian otoritarian adalah 39 dan skor tertinggi 84, rerata empiris $\mathrm{M}=59,8$ dan standar deviasi sebesar 8,4. Data tersebut menunjukkan bahwa rerata empiris hampir sama dengan rerata hipotetis.

Data di atas berarti bahwa reponden dalam penelitian memiliki kepribadian otoritarian lebih tinggi dibanding rerata hipotesisnya. Untuk pengkategorisasian kepribadian otoritarian, maka dibuat tiga kategori yaittu; tinggi, jika skor $>\mathrm{M}+2 \mathrm{~s}(48+2 \mathrm{x} 8,4=64,8=65)$, Sedang, jika skor $\mathrm{M}-2 \mathrm{~s}<\mathrm{X}<\mathrm{M}$ $+2 \mathrm{~s}(31<\mathrm{X}<65)$, dan rendah, jika skor $<\mathrm{M}-2 \mathrm{~s}(<31)$, (Keterangan : $\mathrm{M}=$ Mean teoritis; $\mathrm{s}=$ Standar Deviasi). Berikut tabel 9 menyajikan data kepribadian otoritarian responden yang dikategorikan ke dalam 3 jenis kelas (rendah, sedang, dan tinggi).

Tabel 9 menunjukkan bahwa sebagian besar responden memiliki kepribadian otoritarian dalam kategori sedang yaitu 316 orang atau 73,15\%, kemudian diurutan berikutnya adalah kategori tinggi (113 orang atau $26,15 \%)$ dan tidak ada yang masuk ke dalam kategori rendah $(0,7 \%)$. Ada 3 responden yang dinyatakan missing value.

Tabel 9. Kategorisasi skor kepribadian otoritarian

\begin{tabular}{cccc}
\hline Kategori & Skor & Frekuensi & Prosentase (\%) \\
\hline Tinggi & $>65$ & 113 & 26,15 \\
Sedang & $31<\mathrm{X}<65$ & 316 & 73,15 \\
Rendah & $<31$ & 0 & 0 \\
Missing & - & 3 & 0,7 \\
Total & & 432 & 100 \\
\hline
\end{tabular}

Sumber: hasil skoring skala penelitian 2015 


\section{Data Kepribadian Fundamentalis (X5)}

Secara teoritis, skor masing-masing item skala kepribadian fundamentalis bergerak dari 1 sampai 7 dengan jumlah aitemnya sebanyak 18, maka skor totalnya bergerak dari 18 (12 x 1) sampai dengan 126 (18 x 7). Sehingga luas interval sebarannya adalah $126-18=108$, dengan satuan deviasi standarnya bernilai 108: $6=18$ dan rerata hipotetis sebesar $M=(18+126): 2=72$. Data hasil penelitian menunjukkan bahwa skor terendah skala kepribadian fundamentalis adalah 63 dan skor tertinggi 123, rerata empiris $\quad \mathrm{M}=93,8$ dan standar deviasi sebesar 12,9. Data tersebut menunjukkan bahwa rerata empiris hampir sama dengan rerata hipotetis.

Data di atas berarti bahwa reponden dalam penelitian memiliki kepribadian fundamentalis lebih tinggi dibanding rerata hipotesisnya. Untuk pengkategorisasian kepribadian fundamentalis, maka dibuat tiga kategori yaitu; tinggi, jika skor $>\mathrm{M}+2 \mathrm{~s}(72+2 \mathrm{x} 12,9=97,8=98)$, sedang, jika skor $\mathrm{M}-2 \mathrm{~s}<\mathrm{X}<\mathrm{M}+$ $2 \mathrm{~s}(<66 \mathrm{X}<98)$, dan rendah, jika skor $<\mathrm{M}-2 \mathrm{~s}(<66)$. (Keterangan, $\mathrm{M}=$ Mean teoritis; $\mathrm{s}=\mathrm{Standar}$ Deviasi). Berikut tabel 10 menyajikan data kepribadian fundamentalis responden yang dikategorikan ke dalam 3 jenis kelas (rendah, sedang, dan tinggi).

Tabel 10 menunjukkan bahwa sebagian besar responden memiliki kepribadian fundamentalis dalam kategori sedang yaitu 263 orang atau 60,9\%, kemudian diurutan berikutnya adalah kategori tinggi (150 orang atau $34,7 \%$ ) dan rendah (6 orang atau $0,4 \%$ ). Ada 13 responden yang dinyatakan missing value.

Tabel 10. Kategorisasi skor kepribadian fundamentalis

\begin{tabular}{cccc}
\hline Kategori & Skor & Frekuensi & Prosentase (\%) \\
\hline Tinggi & $>98$ & 150 & 34,7 \\
Sedang & $66<\mathrm{X}<65$ & 263 & 60,9 \\
Rendah & $<66$ & 6 & 0,4 \\
Missing & - & 13 & 3 \\
Total & & 432 & 100 \\
\hline
\end{tabular}

Sumber: hasil skoring skala penelitian 2015

\section{Hasil Uji Hipotesis Penelitian \\ Hipotesis Pertama}

Untuk membuktikan hipotesis 1 , analisis yang digunakan adalah dengan mengunakan analisis regresi berganda dengan 5 variabel bebas dan 1 variabel tergantung. Hasil uji hipotesis diperoleh bahwa kelima variabel memiliki pengaruh yang signifikan terhadap satu variabel tergantung, dengan $\mathrm{F}$ hitung $=18,5$ dan taraf signifikansi $\mathrm{p}=0,000$ (sangat signifikan). Hal ini menunjukkan bahwa identifikasi terhadap kelompok radikal, persepsi ancaman-antar kelompok (baik simbolik maupun realistik),dan kepribadian (baik otoritarian maupun fundamentalis) berpengaruh secara signifikan terhadap pemahaman konsep jihad damai. (hipotesis pertama ditolak). Sumbangan pengaruh kelima variabel (identifikasi terhadap kelompok radikal, persepsi ancaman-antar kelompok simbolik, persepsi ancaman-antar kelompok realistik, kepribadian otoritarian, kepribadian fundamentalis) secara bersama terhadap variabel tergantung (pemahaman konsep jihad damai) adalah 18,3\%, berikut tabel 11 menampilkan hasil regresi berganda untuk membuktikan hipotesis pertama.

Tabel 11. Hasil Analisis Regresi Berganda untuk Hipotesis pertama

\begin{tabular}{cccccc}
\hline $\mathrm{RY}(\mathrm{X} 1, \mathrm{X} 2, \mathrm{X} 3, \mathrm{X} 4, \mathrm{X} 5)$ & $\mathrm{R}$ square & $\mathrm{F}$ & $\mathrm{Db}$ & $\mathrm{P}$ & Sig. \\
\hline 0,428 & 0,183 & 18,47 & 5 & 0,000 & Sangat Signifikan \\
\hline
\end{tabular}

Dari tabel 11 dapat dilihat derajat kebebasan $(\mathrm{db})=5$ yang berarti adanya 5 variabel bebas yang dimasukan dalam model regresi. Harga pengaruh (R) sebesar 0, 428, serta sumbangan efektif R2= 0,183 berarti bahwa sebesar 18,3\% variabel identifikasi terhadap kelompok radikal, persepsi ancamanantar kelompok simbolik, persepsi ancaman-antar kelompok realistik, kepribadian otoritarian, kepribadian fundamentalis mampu memprediksi pemahaman konsep jihad damai, sedangkan sisanya $(100 \%-18,3 \%=81,7 \%)$ dijelaskan oleh prediktor-prediktor yang lain. 
Adapun persamaan regresinya diketahui sebagai berikut:

$\mathrm{Y}=19.572+(-0,076) \mathrm{X} 1+(0,190) \mathrm{X} 2+(-0,003) \mathrm{X} 3+(0,023) \mathrm{X} 4+(0,201) \mathrm{X} 5$

Keterangan:

$\mathrm{Y}=$ pemahaman konsep jihad damai

$\mathrm{X} 1=$ identifikasi terhadap kelompok radikal,

$\mathrm{X} 2=$ persepsi ancaman-antar kelompok simbolik,

$\mathrm{X} 3=$ persepsi ancaman-antar kelompok realistik,

$\mathrm{X} 4=$ kepribadian otoritarian,

$\mathrm{X} 5=$ kepribadian fundamentalis

Konstanta sebesar 19,572 menyatakan bahwa jika tidak ada identifikasi terhadap kelompok radikal, persepsi ancaman-antar kelompok simbolik, persepsi ancaman-antar kelompok realistik, kepribadian otoritarian, kepribadian fundamentalis, maka nilai pemahaman konsep jihad damai adalah sebesar 19,572. Untuk koefisien regresi X1 sebesar -0,076 menyatakan bahwa setiap penambahan 1 unit grade point identifikasi terhadap kelompok radikal, akan menurunkan pemahaman konsep jihad damai sebesar 7,6\%. Koefisien regresi X2 sebesar 0,190 menyatakan bahwa setiap penambahan 1 unit grade point persepsi ancaman-antar kelompok simbolik akan meningkatkan pemahaman konsep jihad damai sebesar 19\%. Koefisien regresi X3 sebesar -0,003 menyatakan bahwa setiap penambahan 1 unit grade point persepsi ancaman-antar kelompok realistik akan menurunkan pemahaman konsep jihad damai sebesar 0,3\%. Koefisien regresi X4 sebesar 0,023 menyatakan bahwa setiap penambahan 1 unit grade point kepribadian otoritarian akan menaikan pemahaman konsep jihad damai sebesar 2,3\%. Demikian untuk Koefisien regresi X5 sebesar 0,201 menyatakan bahwa setiap penambahan 1 unit grade point kepribadian fundamentalis akan menaikan pemahaman konsep jihad damai sebesar $20 \%$.

Dengan demikian berdasarkan hasil persamaan garis regresi, untuk variabel identifikasi terhadap kelompok radikal, persepsi ancaman-antar kelompok simbolik, persepsi ancaman-antar kelompok realistik, kepribadian otoritarian, kepribadian fundamentalis dapat diprediksi bahwa pengaruh terbesar terhadap pemahaman konsep jihad damai adalah kepribadian fundamentalis, kemudian menyusul persepsi ancaman-antar kelompok simbolik dibanding 3 variabel yang laiinya. Kepribadian otoritarian meskipun kecil sumbangannya, namun secara positif memberi sumbangan kepada pemahaman konsep jihad damai. Sementara identikasi terhadap kelompok radikal dan persepsi ancaman antar-kelompok realistik memberikan sumbangan yang negatif, meskipun kecil.

\section{Hipotesis Kedua}

Untuk membuktikan hipotesis 2, analisis yang digunakan adalah dengan mengunakan analisis regresi berganda dengan 5 variabel bebas dan 1 variabel tergantung (pemahaman konsep jihad defensive). Hasil uji hipotesis diperoleh bahwa kelima variabel memiliki pengaruh yang signifikan terhadap satu variabel tergantung, dengan $\mathrm{F}$ hitung $=15,46$ dan taraf signifikansi $\mathrm{p}=0,000$ (sangat signifikan). Hal ini menunjukkan bahwa identifikasi terhadap kelompok radikal, persepsi ancaman-antar kelompok (baik simbolik maupun realistik), dan kepribadian (baik otoritarian maupun fundamentalis) berpengaruh secara signifikan terhadap pemahaman konsep jihad defensif. (hipotesis pertama diterima). Sumbangan pengaruh kelima variabel (identifikasi terhadap kelompok radikal, persepsi ancaman-antar kelompok simbolik, persepsi ancaman-antar kelompok realistik, kepribadian otoritarian, kepribadian fundamentalis) secara bersama terhadap variabel tergantung (pemahaman konsep jihad defensif) adalah $15,8 \%$, berikut tabel 12 menampilkan hasil regresi berganda untuk membuktikan hipotesis kedua.

Tabel 12. Hasil Analisis Regresi Berganda untuk hipotesis kedua

\begin{tabular}{cccccc}
\hline $\mathrm{RY}(\mathrm{X} 1, \mathrm{X} 2, \mathrm{X} 3, \mathrm{X} 4, \mathrm{X} 5)$ & $\mathrm{R}$ square & $\mathrm{F}$ & $\mathrm{Db}$ & $\mathrm{P}$ & Sig. \\
\hline 0,398 & 0,158 & 15,464 & 5 & 0,000 & Sangat Signifikan \\
\hline
\end{tabular}

Dari tabel 12 dapat dilihat derajat kebebasan $(\mathrm{db})=5$ yang berarti adanya 5 variabel bebas yang dimasukan dalam model regresi. Harga pengaruh (R) sebesar 0, 398, serta sumbangan efektif R2= 0,158 berarti bahwa sebesar $15,8 \%$ variabel identifikasi terhadap kelompok radikal, persepsi ancamanantar kelompok simbolik, persepsi ancaman-antar kelompok realistik, kepribadian otoritarian, kepribadian fundamentalis mampu memprediksi pemahaman konsep jihad defensif, sedangkan sisanya $(100 \%-15,8 \%=84,2 \%)$ dijelaskan oleh prediktor-prediktor yang lain. 
Adapun persamaan regresinya diketahui sebagai berikut:

$\mathrm{Y}=17,477+(-0,015) \mathrm{X} 1+(0,246) \mathrm{X} 2+(0,004) \mathrm{X} 3+(0,001) \mathrm{X} 4+(0,174) \mathrm{X} 5$

Keterangan:

$\mathrm{Y}=$ pemahaman konsep jihad defensif

$\mathrm{X} 1=$ identifikasi terhadap kelompok radikal,

$\mathrm{X} 2=$ persepsi ancaman-antar kelompok simbolik,

$\mathrm{X} 3=$ persepsi ancaman-antar kelompok realistik,

$\mathrm{X} 4=$ kepribadian otoritarian,

$\mathrm{X} 2=$ kepribadian fundamentalis

Konstanta sebesar 17, 477 menyatakan bahwa jika tidak ada identifikasi terhadap kelompok radikal, persepsi ancaman-antar kelompok simbolik, persepsi ancaman-antar kelompok realistik, kepribadian otoritarian, kepribadian fundamentalis, maka nilai pemahaman konsep jihad defensif adalah sebesar 17,48. Untuk koefisien regresi X1 sebesar -0,015 menyatakan bahwa setiap penambahan 1 unit grade point identifikasi terhadap kelompok radikal, akan menurunkan pemahaman konsep jihad defensif sebesar 1,5\%. Koefisien regresi X2 sebesar 0,246 menyatakan bahwa setiap penambahan 1 unit grade point persepsi ancaman-antar kelompok simbolik akan meningkatkan pemahaman konsep jihad defensif sebesar 24,6\%. Koefisien regresi X3 sebesar 0,004 menyatakan bahwa setiap penambahan 1 unit grade point persepsi ancaman-antar kelompok realistik akan meningkatkan pemahaman konsep jihad defensif sebesar 0,4\%. Koefisien regresi X4 sebesar 0,001 menyatakan bahwa setiap penambahan 1 unit grade point kepribadian otoritarian akan menaikan pemahaman konsep jihad defensif sebesar $0,1 \%$. Demikian untuk Koefisien regresi X5 sebesar 0,174 menyatakan bahwa setiap penambahan 1 unit grade point kepribadian fundamentalis akan menaikan pemahaman konsep jihad defensif sebesar 17,4\%.

Dengan demikian berdasarkan hasil persamaan garis regresi, untuk variabel identifikasi terhadap kelompok radikal, persepsi ancaman-antar kelompok simbolik, persepsi ancaman-antar kelompok realistik, kepribadian otoritarian, kepribadian fundamentalis dapat diprediksi bahwa pengaruh terbesar terhadap pemahaman konsep jihad defensif adalah kepribadian fundamentalis, kemudian menyusul persepsi ancaman-antar kelompok simbolik dibanding 3 variabel yang lainya. Kepribadian otoritarian persepsi ancaman antar-kelompok realistik meskipun kecil sumbangannya, namun secara positif memberi sumbangan kepada pemahaman konsep jihad defensif. Sementara identikasi terhadap kelompok radikal memberikan sumbangan yang negatif, meskipun kecil. Dari paparan hasil diatas disimpulkan bahwa "Identifikasi terhadap kelompok radikal, persepsi ancaman-antar kelompok (baik simbolik maupun realistik), dan kepribadian (baik otoritarian maupun fundamentalis) berpengaruh secara signifikan terhadap pemahaman konsep jihad defensif", diterima.

\section{Hipotesis Ketiga}

Untuk membuktikan hipotesis 3, analisis yang digunakan adalah dengan mengunakan analisis regresi berganda dengan 5 variabel bebas dan 1 variabel tergantung (pemahaman konsep jihad ofensif). Hasil uji hipotesis diperoleh bahwa kelima variabel memiliki pengaruh yang signifikan terhadap satu variabel tergantung, dengan $\mathrm{F}$ hitung $=13,284$ dan taraf signifikansi $\mathrm{p}=0,000$ (sangat signifikan). Hal ini menunjukkan bahwa identifikasi terhadap kelompok radikal, persepsi ancaman-antar kelompok (baik simbolik maupun realistik), dan kepribadian (baik otoritarian maupun fundamentalis) berpengaruh secara signifikan terhadap pemahaman konsep jihad ofensif. (hipotesis pertama diterima). Sumbangan pengaruh kelima variabel (identifikasi terhadap kelompok radikal, persepsi ancaman-antar kelompok simbolik, persepsi ancaman-antar kelompok realistik, kepribadian otoritarian, kepribadian fundamentalis) secara bersama terhadap variabel tergantung (pemahaman konsep jihad ofensif) adalah 13,3 \%, berikut tabel 13. menampilkan hasil regresi berganda untuk membuktikan hipotesis ketiga.

Tabel 13. Hasil Analisis Regresi Berganda untuk Hipotesis Ketiga

\begin{tabular}{cccccc}
\hline $\mathrm{RY}(\mathrm{X} 1, \mathrm{X} 2, \mathrm{X} 3, \mathrm{X} 4, \mathrm{X} 5)$ & $\mathrm{R}$ square & $\mathrm{F}$ & $\mathrm{Db}$ & $\mathrm{P}$ & Sig. \\
\hline 0,373 & 0,139 & 13,284 & 5 & 0,000 & Sangat Signifikan \\
\hline
\end{tabular}

Dari tabel 13 dapat dilihat derajat kebebasan $(\mathrm{db})=5$ yang berarti adanya 5 variabel bebas yang dimasukan dalam model regresi. Harga pengaruh (R) sebesar 0, 373, serta sumbangan efektif R2 = 0,139 berarti bahwa sebesar 13,9\% variabel identifikasi terhadap kelompok radikal, persepsi ancaman- 
antar kelompok simbolik, persepsi ancaman-antar kelompok realistik, kepribadian otoritarian, kepribadian fundamentalis mampu memprediksi pemahaman konsep jihad ofensif, sedangkan sisanya $(100 \%-15,8 \%=86,1 \%)$ dijelaskan oleh prediktor-prediktor yang lain.

Adapun persamaan regresinya diketahui sebagai berikut:

$\mathrm{Y}=40,630+(0,346) \mathrm{X} 1+(0,236) \mathrm{X} 2+(0,212) \mathrm{X} 3+(-0,256) \mathrm{X} 4+(-0,97) \mathrm{X} 5$

Keterangan:

$\mathrm{Y}=$ pemahaman konsep jihad ofensif

$\mathrm{X} 1=$ identifikasi terhadap kelompok radikal,

$\mathrm{X} 2=$ persepsi ancaman-antar kelompok simbolik,

$\mathrm{X} 3=$ persepsi ancaman-antar kelompok realistik,

$\mathrm{X} 4=$ kepribadian otoritarian,

$\mathrm{X} 2=$ kepribadian fundamentalis

Konstanta sebesar 40,63 menyatakan bahwa jika tidak ada identifikasi terhadap kelompok radikal, persepsi ancaman-antar kelompok simbolik, persepsi ancaman-antar kelompok realistik, kepribadian otoritarian, kepribadian fundamentalis, maka nilai pemahaman konsep jihad ofensif adalah sebesar 40, 63. Untuk koefisien regresi X1 sebesar 0,346 menyatakan bahwa setiap penambahan 1 unit grade point identifikasi terhadap kelompok radikal, akan menaikkan pemahaman konsep jihad ofensif sebesar $34,6 \%$. Koefisien regresi X2 sebesar 0,236 menyatakan bahwa setiap penambahan 1 unit grade point persepsi ancaman-antar kelompok simbolik akan meningkatkan pemahaman konsep jihad ofensif sebesar 23,6\%. Koefisien regresi X3 sebesar 0,212 menyatakan bahwa setiap penambahan 1 unit grade point persepsi ancaman-antar kelompok realistik akan meningkatkan pemahaman konsep jihad defensif sebesar 21,2 \%. Koefisien regresi X4 sebesar -0,256 menyatakan bahwa setiap penambahan 1 unit grade point kepribadian otoritarian akan menurunkan pemahaman konsep jihad ofensif sebesar 25,6\%. Demikian untuk koefisien regresi X5 sebesar -0,97 menyatakan bahwa setiap penambahan 1 unit grade point kepribadian fundamentalis akan menurunkan pemahaman konsep jihad ofensif sebesar 9,7\%.

Dengan demikian berdasarkan hasil persamaan garis regresi, untuk variabel identifikasi terhadap kelompok radikal, persepsi ancaman-antar kelompok simbolik, persepsi ancaman-antar kelompok realistik, kepribadian otoritarian, kepribadian fundamentalis dapat diprediksi bahwa pengaruh terbesar terhadap pemahaman konsep jihad ofensif adalah identifikasi terhadap kelompok radikal, kemudian menyusul persepsi ancaman antar kelompok simbolik dan realistic yang gradenya hamper sama, sedanga kepribadian memiliki pengaruh yang negatif terhadap pemahaman konsep jihad ofensif, terutama untuk kepribadian otoritarian yang lebih besar memberikan sumbangan negatifnya, dibanding kepribadian fundamentalis.

Dari paparan hasil penelitian diatas maka hipotesis yang berbunyi "Identifikasi terhadap kelompok radikal, persepsi ancaman-antar kelompok (baik simbolik maupun realistik),dan kepribadian (baik otoritarian maupun fundamentalis) berpengaruh secara signifikan terhadap pemahaman konsep jihad ofensif" diterima.

\section{Pembahasan}

\section{Pemahaman Konsep Jihad Damai}

Identifikasi kelompok menunjuk pada sejauhmana individu sebagai anggota suatu kelompok merasakan ikatan yang kuat terhadap kelompoknya. (Tajfel,1978). Dari teori ini, dikembangkan asumsi bahwa jika Muslim merasakan ikatan yang kuat dengan kelompok ataupun tokoh radikal Islam, maka ada kemungkinan bahwa mereka memahami Jihad sebagai Jihad ofensif sebagaimana pemahaman dari kelompok yang mereka identifikasikan. Telah disebutkan bahwa kelompok radikal memiliki kecenderungan untuk meyakini konsep Jihad ofensif sebagai satu satunya konsep Jihad yang paling benar (Moghadam, 2008; Muluk \& Sumaktoyo, 2013). Dalam konsteks ini, kelompok radikal Islam justru berpandangan bahwa aksi-aksi sadis seperti bom bunuh diri, penculikan, perampokan, pemenggalan kepala terhadap pihak-pihak yang dipandang sebagai musuh bukanlah aksi terorisme tetapi aksi peperangan suci (holy war) (Hiro, 2014). Berdasarkan logika berpikir yang mengacu pada penjelasan kerangka teori tersebut di atas dimunculkan asumsi bahwa identifikasi tidak berpengaruh terhadap pemahaman jihad damai. Namun ternyata dari penelitian ini ditemukan bahwa identifikasi kelompok memiliki pengaruh, meskipun sedikit terhadap pemahaman konsep jihad damai. Hal ini bisa dimaknai 
bahwa ketika seseorang memahami konsep jihad yang ofensif juga terdapat pemahaman bahwa bentuk jihad juga ada yang damai, Meskipun dalam kenyataannya yang dipraktikan oleh sebagian orang adalah dengan melakukan aksi jihad ofensif.

Hasil penelitian juga menunjukkan bahwa koefisien regresi berganda untuk variabel identifikasi terhadap kelompok radikal sebesar -0,076, hasil ini berarti bahwa setiap penambahan 1 unit grade point identifikasi terhadap kelompok radikal, akan menurunkan pemahaman konsep jihad damai sebesar 7,6\%. Hasil ini dapat menguatkan penjelasan bahwa identifikasi terhadap kelompok radikal memiliki pengaruh pemahaman konsep jihad damai. Pengaruh signifikan dari identifikasi kelompok radikal terhadap pemahaman konsep jihad damai, adalah pengaruh negatif. Artinya bahwa semakin orang mengidentifikasi terhadap kelompok radikal maka akan semakin menurun pemahaman seseorang mengenai konsep jihad damai. Hal ini sesuai dengan pengembangan teori Tajfel (1978) yang dinyatakan bahwa jika muslim merasakan ikatan yang kuat dengan kelompok ataupun tokoh radikal Islam, maka ada kemungkinan bahwa mereka memahami Jihad sebagai Jihad ofensif. Oleh karena itu ketika identifikasi kelompok radikal seseorang adalah rendah, maka kemungkinan seseorang tersebut akan memahami jihad sebagai jihad damai. Demikian juga dapat dijadikan gambaran bahwa mahasiswa STAIN pekalongan, berdasarkan hasil penelitian, memiliki identifikasi kelompok radikal yang relative rendah, oleh karena itu pemahaman yang mereka miliki lebih cenderung kepada pemahaman jihad damai.

Persepsi ancaman antar-kelompok simbolik (symbolic threat) didefinisikan sebagai ancaman yang bersumber dari persepsi bahwa nilai-nilai, norma-norma, pandangan-hidup, dan budaya keompok-lain (outgroups) dianggap bertentangan dan tidak sesuai dengan nilai-nilai, norma-norma, pandangan-hidup, dan budaya kelompok-sendiri (in-group).( Stephan \& Stephan, 2000). Tidak adanya pengaruh persepsi ancaman antar-kelompok simbolik terhadap jihad damai dijelaskan dari apa yang menjadi argumentasi dari Rogers dkk. (2007) yang menyatakan secara umum, persepsi ancaman antar-kelompok, disamping juga perspesi ketidakadilan yang memicu keresahan, menjadi katalis munculya radikalisme dan ekstremisme pada sejumlah kalangan Muslim, yang pada akhirnya memicu aksi-aksi terorisme. Oleh karennya diasumsikan bahwa pemahaman konsep jihad yang damai tidak mungkin dipengaruhi oleh persepsi yang negatif terhadap kelompok lain. Pemahaman konsep damai justru dipengaruhi oleh persepsi yang positif atas keberbedaan prinsip, norma serta nilai kelompok lain, bukan persepsi yang negative atas perbedaan tersebut, apalagi perbedaan tersebut dipersepsi sebagai anacaman. Demikian pula untuk penjelasan persepsi ancaman antar-kelompok yang bersifat realistik (realistic threat) yang diartikan sebagai ancaman yang bermuara pada persepsi bahwa kekuatan ekonomi, kekuasaan ataupun hal-hal lain seperti teknologi yang dimiliki kelompok-lain menyaingi atau lebih tepatnya, mengungguli kelompok-sendiri.(Stephan \& Stephan, 2000).

Namun ternyata persepsi ancaman antar kelompok baik simbolik ataupun realistik juga berpengaruh terhadap pemahaman konsep jihad damai. Hanya saja nilai pengaruhnya sangat kecil. Koefisien regresi untuk persepsi ancaman-antar kelompok simbolik sebesar 0,190, atau dengan kata lain untuk setiap 1 unit grade point persepsi ancaman-antar kelompok simbolik akan meningkatkan pemahaman konsep jihad damai sebesar 19\%. Sedangkan koefisien regresi persepsi ancaman antar kelompok realistik adalah sebesar -0,003, yang artinya bahwa persepsi ancaman antar kelompok realistik memiliki pengaruh yang negative terhadap pemahaman konsep jihad damai Setiap penambahan 1 unit grade point persepsi ancaman-antar kelompok realistik akan menurunkan pemahaman konsep jihad damai sebesar 0,3\%. Semakin persepsi ancaman anatar kelompok yang bersifat realistik akan menurunkan pemahaman konsep jihad damai. Jika dikaitkan dengan teori diatas, dapat dijelaskan bahwa pemahaman konsep damai justru dipengaruhi oleh persepsi yang positif atas keberbedaan prinsip, norma serta nilai kelompok lain, bukan persepsi yang negatif atas perbedaan tersebut, apalagi perbedaan tersebut dipersepsi sebagai ancaman. Dapat diartikan pula bahwa jika persepsi ancaman antar kelompok cenderung ke arah yang negative, maka seseorang akan memiliki kecenderungan yang untuk memahami jihad yang tidak bersifat damai (pemahaman jihad damai yang rendah). Pengaruh negatif dari persepsi ancaman antar kelompok realistik memiliki arti bahwa semakin persepsi ancaman antar kelompok realistik tinggi maka akan semakin rendah pemahaman konsep jihad damai yang dimiliki individu. Hal ini bisa dijelaskan teori tersebut diatas.

Altemeyer (1981, 1988) mendefinisikan bahwa kepribadian otoritarian terdiri dari tiga komponen: (1) ketundukan yang bersifat otoritarian, (2) agresi yang bersifat otoritarian, dan (3) konvesionalisme. Berdasarkan tiga komponen ini, kepribadian otoritarian diartikan sebagai kepribadian yang ditandai 
dengan ketundukan membabi-buta terhadap otoritas, sikap agresif terhadap kelompok-lain yang dianggap menyimpang dari nila-nilai dan budaya kelompok-sendiri, serta fanatisme terhadap nilai-nilai tradisional (Heaven \& Bucci, 2001). Secara lebih spesifik, Gottschalk dan Gottschalk (2004) menemukan bahwa para pelaku teroris yang mengatasnamakan Islam cenderung memiliki kepribadian otoritaran yang kuat. Dari temuan ini, kami berargumen bahwa Muslim dengan kepribadian otoritarian yang kuat berkemungkinan memahami Jihad lebih sebagai Jihad ofensif sebagai bentuk pembenaran atau justifikasi atas kebencian dan ketidaksukaan mereka terhadap orang-orang atau negara Barat. Sedangkan Kepribadian fundamentalis adalah kepribadian yang ditandai dengan keyakinan kuat terahadap kebenaran agama yang diyakini, intoleransi terhadap perdebatan yang bersifat keagamaan serta terhadap pihak-pihak lain yang nilai-nilai dan perilakunya dianggap tidak sesuai dengan standar yang diyakini (Kunst, Thomsen, \& Sam, 2014).Dari penjelasan ini, sebuah premis bisa ditarik dimana kepribadian fundamentalis memiliki tendensi untuk berkontribusi dalam menggiring Muslim untuk memahami Jihad sebagai Jihad ofensif. Hal ini didasarkan pada temuan bahwa para pelaku Jihad ofensif dicirikan dengan adanya kebencian patologis serta intoleransi terhadap pihak-pihak yang dianggap musuh, yang dalam hal ini adalah pihak Barat (Gottschalk dan Gottschalk (2004). Secara empiris, argumen ini sesuai dengan hasil studi dari Muluk dan Sumaktoyo (2013) yang melaporkan bahwa Muslim dengan fundamentalisme beragama yang tinggi cenderung mendukung bentuk atau model Jihad kekerasan.

Namun demikian dalam penelitian ini, hasil yang ditunjukkan adalah berbeda. Kepribadian (baik otoritarian maupun fundamentalis) berpengaruh secara signifikan terhadap pemahaman konsep jihad damai. Hal ini bisa dijelaskan bahwa ketika melihat dari kancah penelitian yang diambil dari penelitian, yaitu pekalongan, diaman secara kultur, warga di pekalongan memiliki keragaman corak dalam beragama, corak cultural NU dan Muhamadiyyah, dimana jika dilihat dari sisi kepribadian yang muncul dari kelompok ormas terbesar di Pekalongan ini juga merujuk kepada ciri kepribadian otoritarian dan fundamentalis. Mereka dicirikan kepada salah satu indikator keyakinan kuat terahadap kebenaran agama yang diyakini, dari indikator inilah pemahaman konsep jihad damai dipengaruhi oleh kedua jenis kepribadian ini. Keyakinan kuat terhadap kebenaran agama yang diyakini, denga diiringi penafsiran yang tidak tekstual mampu melahirkan pemahaman konsep jihad damai, dimana kedamaian merupakan bagian dari keyakinan kuat akan kebenaran agama yang diyakininya.

Pemahaman Konsep Jihad Defensif

Diasumsikan bahwa "Identifikasi terhadap kelompok radikal, persepsi ancaman-antar kelompok (baik simbolik maupun realistik), dan kepribadian (baik otoritarian maupun fundamentalis) berpengaruh secara signifikan terhadap pemahaman konsep jihad defensif", secara empirik ditemukan bahwa kelima variabel bebas memiliki pengaruh yang signifikan terhadap pemahaman konsep jihad defensif.

Pemahaman konsep jihad defensif berbeda dengan pemahaman jihad damai, dimana pemahaman yang merujuk kepada pemahaman bahwa jihad itu adalah untuk mempertahankan hak atas pribadi dari serangan orang lain. Sehingga jihad difahami sebagai perilaku yang apabila dalam keadaan darurat maka jihad dapat dilaksanakan. Sesuai penjelasan teori yang dipaparkan dalam penjelasan dan pembahasan pemahaman jihad damai telah dirinci berdasarkan variabel yang mempengaruhi pemahaman konsep jihad jihad. Jihad pada hakikatnya dimaksudkan untuk terjaminnya kelangsungan system ajaran Islam hingga akhir zaman (Al-Sya'rawi,2011), demikian setidaknya dasar yang mengawali seseorang memahami konsep jihad dengan defensif. Ketika seseorang memiliki identifikasi terhadap kelompok radikal, maka kecenderungan seseorang untuk memiliki pemahaman konsep jihad yang ofensif adalah nyata.

Sumbangan pengaruh kelima variabel (identifikasi terhadap kelompok radikal, persepsi ancaman-antar kelompok simbolik, persepsi ancaman-antar kelompok realistik, kepribadian otoritarian, kepribadian fundamentalis) secara bersama terhadap variabel tergantung (pemahaman konsep jihad defensif) adalah 15,8 \%, sedangkan sisanya adalah dari variabel lain. Sumbangan terbesar dari kelima variabel adalah variabel persepsi ancaman simbolik $(24,6 \%)$, kemudian kepribadian fundamentalis $(17,4 \%)$, sedangkan persepsi ancaman realistik $(0,4 \%)$ dan kepribadian otoritarian $(0,1 \%)$ hanya menyumbang sedikit, apalagi identifikasi kelompok terhadap radikalisme, variabel terakhir ini memiliki pengaruh yang negatif.

Identifikasi kelompok menunjuk pada sejauhmana individu sebagai anggota suatu kelompok merasakan ikatan yang kuat terhadap kelompoknya. (Tajfel,1978). Dari teori ini, dikembangkan asumsi bahwa 
jika Muslim merasakan ikatan yang kuat dengan kelompok ataupun tokoh radikal Islam, maka ada kemungkinan bahwa mereka memahami Jihad sebagai Jihad ofensif sebagaimana pemahaman dari kelompok yang mereka identifikasikan. Telah disebutkan bahwa kelompok radikal memiliki kecenderungan untuk meyakini konsep Jihad ofensif sebagai satu satunya konsep Jihad yang paling benar (Moghadam, 2008; Muluk \& Sumaktoyo, 2013). Dalam konsteks ini, kelompok radikal Islam justru berpandangan bahwa aksi-aksi sadis seperti bom bunuh diri, penculikan, perampokan, pemenggalan kepala terhadap pihak-pihak yang dipandang sebagai musuh bukanlah aksi terorisme tetapi aksi peperangan suci (holy war) (Hiro, 2014). Berdasarkan logika berpikir yang mengacu pada penjelasan kerangka teori tersebut di atas dimunculkan asumsi bahwa identifikasi berpengaruh terhadap pemahaman jihad defensif, karena meskipun motifnya berbeda, namun jihad ofensif dan jihad defensif memiliki bentuk yang sama, yaitu melakukan jihad dengan peperangan. Hanya saja jihad defensif adalah peperangan hanya jika ketika diserang oleh musuh, sedang jihad ofensif motifnya adalah untuk ekspansi.

Hasil penelitian juga menunjukkan bahwa koefisien regresi berganda untuk variabel identifikasi terhadap kelompok radikal sebesar - 0,015 , hasil ini berarti bahwa setiap penambahan 1 unit grade point identifikasi terhadap kelompok radikal, akan menurunkan pemahaman konsep jihad damai sebesar 1,5\%. Hasil ini dapat menguatkan penjelasan bahwa identifikasi terhadap kelompok radikal memiliki pengaruh pemahaman konsep jihad defensif. Pengaruh signifikan dari identifikasi kelompok radikal terhadap pemahaman konsep jihad defensif, adalah pengaruh negatif. Artinya bahwa semakin orang mengidentifikasi terhadap kelompok radikal maka akan semakin menurun pemahaman seseorang mengenai konsep jihad defesif. Hal ini sesuai dengan pengembangan teori Tajfel (1978) yang menyatakan bahwa jika muslim merasakan ikatan yang kuat dengan kelompok ataupun tokoh radikal Islam, maka ada kemungkinan bahwa mereka memahami Jihad sebagai Jihad ofensif. Oleh karena itu ketika identifikasi kelompok radikal seseorang adalah rendah, maka kemungkinan seseorang tersebut akan memahami jihad sebagai jihad damai. Demikian jugadapat dijadikan gambaran bahwa mahasiswa STAIN pekalongan, berdasarkan hasil penelitian, memiliki identifikasi kelompok radikal yang relatif rendah, oleh karena itu pemahaman yang mereka miliki lebih cenderung kepada pemahaman jihad defensif. Sama halnya seperti yang dijelaskan untuk pembahasan identifikasi memiliki pengaruh negative terhadap pemahaman konsep jihad damai.

Sumbangan terbesar dari kelima variabel adalah variabel persepsi ancaman simbolik (24,6\%). Persepsi ancaman antar-kelompok simbolik (symbolic threat) didefinisikan sebagai ancaman yang bersumber dari persepsi bahwa nilai-nilai, norma-norma, pandangan-hidup, dan budaya keompok-lain (outgroups) dianggap bertentangan dan tidak sesuai dengan nilai-nilai, norma-norma, pandangan-hidup, dan budaya kelompok-sendiri (in-group).( Stephan \& Stephan, 2000).

Pengaruh persepsi ancaman antar-kelompok simbolik terhadap jihad defensif dapat dijelaskan dari apa yang menjadi argumentasi dari Rogers dkk. (2007) yang menyatakan secara umum, persepsi ancaman antar-kelompok, disamping juga perspesi ketidakadilan yang memicu keresahan, menjadi katalis munculya radikalisme dan ekstremisme pada sejumlah kalangan Muslim, yang pada akhirnya memicu aksi-aksi terorisme. Pada pemahaman konsep jihad defensif, munculnya aksi-aksi radikal adalah dalam rangka untuk mempertahankan diri. Persepsi ketidakadilan yang mengancam setidaknya ikut mempengauhi seseorang melakukan perlawanan ataupun pertahanan diri. Oleh karennya diasumsikan bahwa persepsi ancaman baik simbolik maupun realistic akan mempengaruhi pemahaman konsep jihad defensif. Dan hal ini terbukti dari hasil penelitian ini.

Altemeyer (1981, 1988) mendefinisikan bahwa kepribadian otoritarian terdiri dari tiga komponen: (1) ketundukan yang bersifat otoritarian, (2) agresi yang bersifat otoritarian, dan (3) konvesionalisme. Berdasarkan tiga komponen ini, kepribadian otoritarian diartikan sebagai kepribadian yang ditandai dengan ketundukan membabi-buta terhadap otoritas, sikap agresif terhadap kelompok-lain yang dianggap menyimpang dari nila-nilai dan budaya kelompok-sendiri, serta fanatisme terhadap nilai-nilai tradisional (Heaven \& Bucci, 2001). Secara lebih spesifik, Gottschalk dan Gottschalk (2004) menemukan bahwa para pelaku teroris yang mengatasnamakan Islam cenderung memiliki kepribadian otoritaran yang kuat. Dari temuan ini, kami berargumen bahwa Muslim dengan kepribadian otoritarian yang kuat berkemungkinan memahami Jihad lebih sebagai Jihad ofensif sebagai bentuk pembenaran atau justifikasi atas kebencian dan ketidaksukaan mereka terhadap orang-orang atau negara Barat. Sedangkan Kepribadian fundamentalis adalah kepribadian yang ditandai dengan keyakinan kuat terahadap kebenaran agama yang diyakini, intoleransi terhadap perdebatan yang bersifat keagamaan 
serta terhadap pihak-pihak lain yang nilai-nilai dan perilakunya dianggap tidak sesuai dengan standar yang diyakini (Kunst, Thomsen, \& Sam, 2014). Dari penjelasan ini, sebuah premis bisa ditarik dimana kepribadian fundamentalis memiliki tendensi untuk berkontribusi dalam menggiring Muslim untuk memahami Jihad sebagai Jihad ofensif. Hal ini didasarkan pada temuan bahwa para pelaku Jihad ofensif dicirikan dengan adanya kebencian patologis serta intoleransi terhadap pihak-pihak yang dianggap musuh, yang dalam hal ini adalah pihak Barat (Gottschalk dan Gottschalk (2004). Secara empiris, argumen ini sesuai dengan hasil studi dari Muluk dan Sumaktoyo (2013) yang melaporkan bahwa Muslim dengan fundamentalisme beragama yang tinggi cenderung mendukung bentuk atau model Jihad kekerasan. Penjelasan tersebut juga dapat dijadikan sebagai landasan bahwa kepribadian baik otoritarian maupun fundamentalis berpengaruh terhadap pemahaman konsep jihad defensif.

Pemahaman Konsep Jihad Ofensif.

Diasumsikan bahwa "Identifikasi terhadap kelompok radikal, persepsi ancaman-antar kelompok (baik simbolik maupun realistik), dan kepribadian (baik otoritarian maupun fundamentalis) berpengaruh secara signifikan terhadap pemahaman konsep jihad ofensif", secara empirik ditemukan bahwa kelima variabel bebas memiliki pengaruh yang signifikan terhdapa pemahaman konsep jihad ofensif. Sumbangan pengaruh kelima variabel (identifikasi terhadap kelompok radikal, persepsi ancaman-antar kelompok simbolik, persepsi ancaman-antar kelompok realistik, kepribadian otoritarian, kepribadian fundamentalis) secara bersama terhadap variabel tergantung (pemahaman konsep jihad ofensif) adalah 13,3\%, sedangkan sisanya adalah dari variabel lain. Sumbangan terbesar dari kelima variabel adalah identifikasi kelompok terhadap radikalisme (34,6\%), kemudian secara berurutan adalah persepsi ancaman-antar kelompok simbolik (23,6\%) dan, persepsi ancaman-antar kelompok realistic $(21,2 \%)$, sedang kepribadian baik otoritarian $(25,6 \%)$ maupun fundamentalis $(9,7 \%)$ memiliki pengaruh yang negatif.

Identifikasi kelompok menunjuk pada sejauhmana individu sebagai anggota suatu kelompok merasakan ikatan yang kuat terhadap kelompoknya. (Tajfel,1978). Dari teori ini, dikembangkan asumsi bahwa jika Muslim merasakan ikatan yang kuat dengan kelompok ataupun tokoh radikal Islam, maka ada kemungkinan bahwa mereka memahami Jihad sebagai Jihad ofensif sebagaimana pemahaman dari kelompok yang mereka identifikasikan. Telah disebutkan bahwa kelompok radikal memiliki kecenderungan untuk meyakini konsep Jihad ofensif sebagai satu satunya konsep Jihad yang paling benar (Moghadam, 2008; Muluk \& Sumaktoyo, 2013). Dalam konsteks ini, kelompok radikal Islam justru berpandangan bahwa aksi-aksi sadis seperti bom bunuh diri, penculikan, perampokan, pemenggalan kepala terhadap pihak-pihak yang dipandang sebagai musuh bukanlah aksi terorisme tetapi aksi peperangan suci (holy war) (Hiro, 2014). Berdasarkan logika berpikir yang mengacu pada penjelasan kerangka teori tersebut di atas dimunculkan asumsi bahwa identifikasi berpengaruh terhadap pemahaman jihad ofensif.

Hasil penelitian juga menunjukkan bahwa koefisien regresi berganda untuk variabel identifikasi terhadap kelompok radikal menyumbang paling besar diantara variabel lain terhadapa pemahaman konsep jihad ofensif. Hasil ini menguatkan apa yang telah diteorikan diatas. Hal ini juga sesuai dengan pengembangan teori Tajfel (1978) yang menyatakan bahwa jika muslim merasakan ikatan yang kuat dengan kelompok ataupun tokoh radikal Islam, maka ada kemungkinan bahwa mereka memahami Jihad sebagai Jihad ofensif.

Pengaruh persepsi ancaman antar-kelompok simbolik terhadap jihad defensif dapat dijelaskan dari apa yang menjadi argumentasi dari Rogers dkk. (2007) yang menyatakan secara umum, persepsi ancaman antar-kelompok, disamping juga perspesi ketidakadilan yang memicu keresahan, menjadi katalis munculya radikalisme dan ekstremisme pada sejumlah kalangan Muslim, yang pada akhirnya memicu aksi-aksi terorisme. Pada pemahaman konsep jihad defensif, munculnya aksi-aksi radikal adalah dalam rangka untuk mempertahankan diri. Persepsi ketidakadilan yang mengancam setidaknya ikut mempengauhi seseorang melakukan perlawanan ataupun pertahanan diri. Oleh karennya diasumsikan bahwa persepsi ancaman baik simbolik maupun realistic akan mempengaruhi pemahaman konsep jihad defensif. Dan hal ini terbukti dari hasil penelitian ini.

Altemeyer (1981, 1988) mendefinisikan bahwa kepribadian otoritarian terdiri dari tiga komponen: (1) ketundukan yang bersifat otoritarian, (2) agresi yang bersifat otoritarian, dan (3) konvesionalisme. Berdasarkan tiga komponen ini, kepribadian otoritarian diartikan sebagai kepribadian yang ditandai dengan ketundukan membabi-buta terhadap otoritas, sikap agresif terhadap kelompoklain yang dianggap menyimpang dari nila-nilai dan budaya kelompok-sendiri, serta fanatisme terhadap 
nilai-nilai tradisional (Heaven \& Bucci, 2001). Secara lebih spesifik, Gottschalk dan Gottschalk (2004) menemukan bahwa para pelaku teroris yang mengatasnamakan Islam cenderung memiliki kepribadian otoritaran yang kuat. Dari temuan ini, kami berargumen bahwa Muslim dengan kepribadian otoritarian yang kuat berkemungkinan memahami Jihad lebih sebagai Jihad ofensif sebagai bentuk pembenaran atau justifikasi atas kebencian dan ketidaksukaan mereka terhadap orang-orang atau negara Barat. Sedangkan Kepribadian fundamentalis adalah kepribadian yang ditandai dengan keyakinan kuat terahadap kebenaran agama yang diyakini, intoleransi terhadap perdebatan yang bersifat keagamaan serta terhadap pihak-pihak lain yang nilai-nilai dan perilakunya dianggap tidak sesuai dengan standar yang diyakini (Kunst, Thomsen, \& Sam, 2014).Dari penjelasan ini, sebuah premis bisa ditarik dimana kepribadian fundamentalis memiliki tendensi untuk berkontribusi dalam menggiring Muslim untuk memahami Jihad sebagai Jihad ofensif. Hal ini didasarkan pada temuan bahwa para pelaku Jihad ofensif dicirikan dengan adanya kebencian patologis serta intoleransi terhadap pihak-pihak yang dianggap musuh, yang dalam hal ini adalah pihak Barat (Gottschalk dan Gottschalk (2004). Secara empiris, argumen ini sesuai dengan hasil studi dari Muluk dan Sumaktoyo (2013) yang melaporkan bahwa Muslim dengan fundamentalisme beragama yang tinggi cenderung mendukung bentuk atau model Jihad kekerasan (ofensif). Hal ini terbukti dari hasil penelitian ini.

\section{Kesimpulan}

Dari hasil penelitian, dismpulkan bahwa :

1. Identifikasi terhadap kelompok radikal, Persepsi ancaman-antar kelompok (baik simbolik maupun realistik), dan kepribadian (baik otoritarian maupun fundamentalis) berpengaruh positif secara signifikan terhadap pemahaman konsep jihad damai;

2. Identifikasi terhadap kelompok radikal, Persepsi ancaman-antar kelompok (baik simbolik maupun realistik), dan kepribadian (baik otoritarian maupun fundamentalis) berpengaruh positif secara signifikan terhadap pemahaman konsep jihad defensif;

3. Identifikasi terhadap kelompok radikal, Persepsi ancaman-antar kelompok (baik simbolik maupun realistik), dan kepribadian (baik otoritarian maupun fundamentalis) berpengaruh positif secara signifikan terhadap pemahaman konsep jihad ofensif.

Besarnya pengaruh kelima variabel bebas terhadap tiga variabel tergantung adalah berbeda-beda. Pengaruh terbesar adalah ketika kelima variabel bebas penelitian mempengaruhi pemahaman konsep jihad damai (18,3\%), kemudian pemahaman konsep jihad defensif (15,8\%), dan yang terakhir pemahaman konsep jihad ofensif (13,9\%).

\section{Ucapan Terima Kasih}

Peneliti mengucapkan banyak terima kasih kepada IAIN Pekalongan yang dengan dana DIPA tahun 2015 (pada tahun tersebut masih berstatus STAIN Pekalongan) mensupport jalannya penelitian ini. Semoga ke depan IAIN Pekalongan semakin jaya dan maju.

\section{Daftar Pustaka}

Al-Sya'rawi, M.M. (2011). Jihad dalam Islam. Jakarta: Republika.

Lindzey \& Hall. (1993). Teori-teori Holistik (Organismik-Fenomenologis). jilid 1, Yogyakarta: Kanisius

Sears, David O, Freedman, JonathanL. Peplau, \& Letitia A. (1994). Psikologi Sosial. Jilid 2. Edisi kelima (terjemah). Jakarta: Erlangga

Ahmad, E. (2011). Terrorism: theirs \& ours. Seven Stories Press.

Al-alusi, Shihabudin Mahmud ibn Abdullah. (tt). Ruhul ma'ani fi tafsiril qur'an al-adzim. Juz 15.

Mawqi' al-Tafasir Al-nabhani, T. (1994). asl-syahsiyyah al islamaiyyah. Beirut: Dar al-Ummah.

Al-Qaradhawi, Y. (2009). Fiqh Of Jihad. Maktabah Wahbah. Kairo

Al-Qardhawi. (1993). Sistem Kaderisasi Ikhwan Al-Muslimin. (Terjemah Ghazali Mukri). Solo: Pustaka Mantiq

Altemeyer, B. (1981). Right-wing authoritarianism. Winnipeg, Canada: University of Manitoba Press.

Altemeyer, B., \& Hunsberger, B. (1992).Authoritarianism, religious fundamentalism, quest, and prejudice.The International Journal for the Psychology of Religion, 2(2), 113-133. 
Altemeyer, Bob. (1988). Enemies of freedom: Understanding right wing authoritarianism. San Francisco: Jossey-Bass.

Asthana, N. C., \& Nirmal, A. (2009). Urban terrorism: Myths and realities. Jaipur: Pointer Publications.

Blair, T. (October 14, 2014). Fight war of ideas against extremism. BBC News. Retrieved February 25, 2015 from http://www.bbc.com/news/business-29553001

Duckitt, J. (2006). Differential effects of right wing authoritarianism and social dominance orientation on outgroup attitudes and their mediation by threat from and competitiveness to outgroups. Personality and Social Psychology Bulletin, 32(5), 684-696.

Fair, C.C, \& Shepherd, B. (2006). Who supports terrorism? Evidence from fourteen Moslem countries.Studies in Conflict \& Terrorism, 29, 51-74.

Gottschalk, M., \& Gottschalk, S. (2004). Authoritarianism and pathological hatred: A social psychological profile of the Middle Eastern terrorist. The American Sociologist, 35(2), 38-59.

Gravetter, F., \& Forzano, L. A. (2015).Research methods for the behavioral sciences. Cengage Learning.

Hayes, A. F. (2013). Introduction to mediation, moderation, and conditional process analysis: A regression-based approach. Guilford Press.

Heaven, P. C., \& Bucci, S. (2001). Right wing authoritarianism, social dominance orientation and personality: an analysis using the IPIP measure. European Journal of Personality, 15(1), 49-56.

Hiro, D. (2014). War without end: the rise of Islamist terrorism and global response. Routledge.

Indonesia arrests six people, including 10-year-old child, for attempting to join Islamic State. December 27, 2014. Retrieved February 25, 2015 diakses melalui http://www.abc.net.au/news/2014-12-27/indonesia-arrests-six-attempting-to-join-ismilitants/5989998

Jannati, A. (1984). Defence and Jihad in the Qur'an. Diakses melalui http://www.al-islam.org

Kabir, N. (2006). Representation of Islam and Muslims in the Australian media, 2001-2005.Journal of Muslim Minority Affairs, 26(3), 313-328.

Khān, V. (2002). The true jihad: the concepts of peace, tolerance, and non-violence in Islam. goodword.

King, M., \& Taylor, D. M. (2011). The radicalization of homegrown jihadists: A review of theoretical models and social psychological evidence. Terrorism and Political Violence, 23(4), 602-622.

Kirkpratick, D. D. (February 16, 2015). Egypt Launches Airstrike in Libya Against ISIS Branch. Retrieved February 25, 2015 diakses melalui http://www.nytimes.com/2015/02/17/world/middleeast/isis-egypt-libya-airstrikes.html?_r=0

Kunst, J. R., Thomsen, L., \& Sam, D. L. (2014).Late Abrahamic reunion? Religious fundamentalism negatively predicts dual Abrahamic group categorization among Muslims and Christians. European Journal of Social Psychology, 44(4), 337-348.

Labib, R. 2007. Jihad Ofensif : Tafsir QS at-Taubah ayat 123. diakses melalui https://ainuamri.wordpress.com pada tanggal 26/02/2015

Mashuri, A. \& Zaduqisti, E. 2014. The role of social identification, intergroup threat, and out-group derogation in explaining belief in conspiracy theory about terrorism in Indonesia. International Journal of Research Studies in Psychology. Vol 3 (1) , 35-50

Mashuri, A., Zaduqisti, E., Sakdiah, H., \& Sukmawati, F. (2014).The role of identity subversion in structuring the effects of intergroup threats and group dejection on belief in conspiracy theories in Indonesia. Paper submitted for publication.

Mashuri, A., \& Zaduqisti, E. (2016). You are the real terrorist and we are just your puppet: The indirect effect of Muslim's religious fundamentalism on attribution of terrorism. Europe's journal of psychology 12 (1), 68-98

Muniroh,S.M., Maghfur, A., Ula, M. 2012. "Perempuan di Balik Teroris: Kajian Religiusitas, Penyesuaian Diri dan Pola Relasi Suami Isteri Tersangka Teroris". "Best Paper and Presentation Award" pada ajang Annual International Conference on Islamic Studies (AICIS) 2012 di Empire Palace Hotel Surabaya, 5-8 Nopember.

Moghadam, A. (2008). The globalization of martyrdom: Al Qaeda, Salafi Jihad, and the diffusion of suicide attacks. JHU Press.

Moghaddam, F. M. (2012). The omnicultural imperative. Culture \& Psychology, 18(3), 304-330. 
Muluk, H., Sumaktoyo, N. G., \& Ruth, D. M. (2013). Jihad as justification: National survey evidence of belief in violent jihad as a mediating factor for sacred violence among Muslims in Indonesia. Asian Journal of Social Psychology, 16(2), 101-111.

Post, J., Sprinzak, E., \& Denny, L. (2003). The terrorists in their own words: Interviews with 35 incarcerated Middle Eastern terrorists. This research was conducted with the support of the Smith Richardson Foundation. Terrorism and political Violence, 15(1), 171-184.

Putra, I. E., \& Sukabdi, Z. A. (2013). Basic concepts and reasons behind the emergence of religious terror activities in Indonesia: An inside view. Asian Journal of Social Psychology, 16(2), 83-91.

Putra, I. E., \& Sukabdi, Z. A. (2014). Can Islamic fundamentalism relate to nonviolent support? The role of certain conditions in moderating the effect of Islamic fundamentalism on supporting acts of terrorism. Peace and Conflict: Journal of Peace Psychology, 20(4), 583.

Riek, B. M., Mania, E. W., \& Gaertner, S. L. (2006). Intergroup threat and outgroup attitudes: A metaanalytic review. Personality and Social Psychology Review, 10(4), 336-353.

Rogers, M. B., Loewenthal, K. M., Lewis, C. A., Amlôt, R., Cinnirella, M., \& Ansari, H. (2007). The role of religious fundamentalism in terrorist violence: A social psychological analysis. International Review of Psychiatry, 19(3), 253-262.

Said, A. A., Funk, N. C., \& Kunkle, L. M. (2001). The role of faith in cross-cultural conflict resolution. Presentation at the European Parliament for the European Centre for Common Ground.

Shihab, Q. 1996. Wawasan Al-Quran, Tafsir Maudhu'i atas Pelbagai Persoalan Umat . Bandung: Mizan.

Sindic, D., \& Reicher, S. D. (2009). 'Our way of life is worth defending': testing a model of attitudes towards superordinate group membership through a study of Scots' attitudes towards Britain. European Journal of Social Psychology, 39(1), 114-129.

Stephan, W. G., \& Stephan, C. W. (2000). An integrated threat theory of prejudice. In S. Oskamp (Ed.), Claremont symposium on applied social psychology (pp.23-46). Hillsdale, NJ: Erlbaum.

Sultana, A. (2008). Digging Islamic roots of Jihad to unveil the truth. Politikologija religije, 2(1), 31-42.

Werbner, P. (2005). Islamophobia: Incitement to religious hatred-legislating for a new fear?.Anthropology today, 21(1), 5-9.

Zakrisson, I. (2005). Construction of a short version of the Right-Wing Authoritarianism (RWA) Scale. Personality and Individual Differences, 39(5), 863-872. 